\title{
The Legal Technology Mistake and Mistake in Qualifying: Cause and Effect
}

\author{
Michail M. Onishchuk ${ }^{1}$
}

Irina V. Klimova²

\section{Elena A. Pashchenko ${ }^{3}$}

\author{
${ }^{1}$ Russian Presidential Academy of National Economy and Public Administration. South-Russian Institute of \\ Management Rostov-on-Don, Russia; ${ }^{2}$ Southern Federal University, Taganrog, Russia; ${ }^{3}$ Russian Presidential Academy of \\ National Economy and Public Administration. South-Russian Institute of Management, Rostov-on-Don, Russia
}

Doi:10.5901/mjss.2015.v6n6s3p290

\begin{abstract}
The scientific article represents the research of the different kinds of mistakes and the reasons and the data of the normative estimations in order to minimize the delinquency activity. The criminal law is the aggregation of the criminally management activity in the cooperation with the practical and the theory data. What often doesn't represent the deal and the coordination this two groups. It often faces because of the fuzzy law system on Russia and the often changes in it. All of them represent huge ideas in the criminal law research, but I think the idea is not fully researched all signs of a perfect face criminal acts constituting. In connection with the above, it is important to explore the issue of criminal legal error when the wrong person evaluates the legal or factual circumstances of the crime. It should be noted that the problem of errors (in the broad sense, not only the criminal law) is beyond the scope of their study separate science (in particular, criminal law). The study of errors of human behavior pays attention to the different Sciences: psychology, economy, management, sociology, etc. No one is immune from mistakes in their behavior, and only part of the human error falls within the scope of their study of criminal law. The methods using in my dissertation are: the regulation, the compare analysis, statistics, saving. This deteriorates the governance parameters.
\end{abstract}

Keywords: mistake in qulifing, legislative formation, regulatory material, law enforcement, legal techology.

\section{Introduction}

Subject mistakes are traditionally referred to option confusion with a subsequent impact as the offense qualification. It is harder to solve problems of qualification issues, if the delusion is "allowed" by law. Russian lawmakers should stipulate the concept and implications of factual mistakes, and eliminate under the law contradiction, has been allowed it.

Deviant behavior does not mean, of course, the adsense of liability criminal societyin legal training, lack of content law understanding. In some cases we are faced with a good knowledge of the subjects in normative material, especially in cases of economic crime and crimes against property. It is the worst situation for lawyers when the legislator is a fertile ground for possible abuse, and when the bugs legislative techniques "work" for the benefit of the subjects. A crime is made up of two elements basically, the first is the the actual doing of the criminal action, and the second element is the intent of commeting the crime. The act of the crime is "actus reus" in Latin, and the intent is "mens rea". However in many crimes the term "strict liability" is used because there are cases where it is not necessary to show pre-existing criminal intention.

When a crime was physically acted because of a mistake in facts, thus without forming mens rea, liability of the offenses that require mens rea can be escaped. Unlike mistakes in law, wich do not lift any liability (Elements of Crimes. International Criminal Court (2011). http://www.icc-cpi.int/NR/rdonlyres/threethreesixninetwothreeD8-AsixAD-fourtyECADsevenBfourfiveBFnineDEseventhreeDfivesix/zero/ElementsOfCrimesEng.pdf.).

The legislator can not entitle disregarding, ignoring the increase of socio-political awareness the population and the crimes intellectualization processes in the Russian Federation (Elements of Crimes. International Criminal Court (2011). http://www.icc-cpi.int/NR/rdonlyres/336923D8-A6AD-40EC-AD7B45BF9DE73D56/0/ElementsOfCrimesEng.pdf.). And this fact should form a more responsible approach to lawmaking, compliance and restraint the rules and preporation methods in regulatory proposals to avoid mistakes in management activity. It ts too premature to talk about perfection of legal material in the modern law materal management. Though there are many works in the modern law analysies, 
written by many experts like: A. Boiko, N., G.Gareliva, Tagancev, B. D. Friedman, P. C. Gagel, G. A. Zlobin, A. A. Piontkovsky, A. N. Battle, A. A. Gartenzaun, B. S. Nikiforov, B. C. Utevsky, IG. The Filanovsky, H. H. Korzenski, C. J. Tatsiy, T. A. Kostareva, T. C. Kondrashova, N, etc. It is suffice to recall the situation, with the former currently in force, special fraud under article number 159.4 in the criminal code of Russia, when the error of the legislative building led to the violation of fundamental provisions in the criminal law (Harald, 2015). This legislator norm has provided undue advantage in the form of commutation persons because of their belonging to a social group of entrepreneurs and employees of commercial organizations. It is shown in sociological and psychological literature that a desire for autonomy and independence with the willingness to ignore rules and conventions can lead either to criminal activity or to new business ventures.

By order dated December 11, 2014 N 32-P of the constitutional Court assessed the constitutionality of the provisions in article number one hundred fifty-nine point four of the Criminal code of the Russian Federation. (Criminal Law, 2015).

\section{The Informative Fraud Liability Trands in the Crininal Code}

Part 3 of article one hundred fifty-nine point four of the Criminal code of the Russian Feredation provided for fraud liability with the former currently in force in the case of mistake in the legislative building what leads to the violation in the fundamental provisions in the criminal law (Daniel, E. Hall., 2015). The legislator has provided this norm undue advantage in the form of commutation persons because of their belonging to a social group of entrepreneurs and employees of commercial organizations. By order dated December 11, 2014 N 32-P of the constitutional Court assessed the constitutionality of the provisions of article one hundred fifty-nine point four of the Criminal code in the Russian Federation. Part 3 of article one hundred fifty-nine point fourof the criminal code provided for liability for fraud, combined with the deliberate ignoring of obligation mentioned in contracts, in the sphere of entrepreneurial activity, in especially large size, and its punishment, including deprivation of liberty for a term up to five years Australian Estates P/L v Cairns City Council (2015).

At the same time Part 4 of the article one hundred fifty-nine of the Criminal code committed fraud by an organized group or one with a big number on people. It is caused the deprivation of a citizen's right to housing, provides for the punishment of imprisonment up to 10 years. The regrettable that the legislature of the error is not harmless for adequate protection of the rights and interests of the victim decision; it is a category that affect the limits of liability and punishment of the subject. The legal nature, the actual content of the identified types of legal or factual mistake.

There are specific examples of law difficulties enforcement caused by the contradictions of legislative structures, have already been considered by E.A. Pashchenko (Paschenko, 2012). When a group of criminals run a centralized, national or transnational enterprise based on illegal activity wich is most commonly intended to make money and profits, this is called organized crime. Politically motivated criminal organizations are mostly terrorist groups. Sometimes people are forced to work with criminal organizations, such as "protection" money thay shop-keepers have to give to gangs. If gangs become disciplined enough they can be considered organized. A mob or a crime syndicate; the network; are also names for criminal organization, the underworld is the subculture and community of criminals. Arms smuggling, drug trafficking and financial crime make organized crime a lot of money.

The problem with the legal technology is covered in I. V.Thibeault scientific works and estimated by cognitive modeling (Thibeault, Prichina, Goreliva \& Galina, 2015). Criminal mistakes are covered by A.I.Boiko also as an economical- juridical problem.

Thus, the norm represented in the Criinal Law articles in the Russian Federation added a note, according to which the crimes provided by point "b" of the fourth part of article 131 and paragraph "b" of the fourth part of article 132 of the criminal code, are also acts that fall under the signs of the crimes provided by parts three - five of article 134 and parts two - four of article 135 of the criminal code committed against a person under twelve years of age, since this person because of age is in a helpless state, that is, unable to understand the nature and importance of committed action with him. Considering the changes in the compositions of violent and non-violent sexual offences listed in the Criminal code relating to criminal responsibility for sexual assault against a minor, it should be stated they are not well founded, and as a consequence efficiency. The legislator did not take into account the doctrinal status of a science of criminal law and enforcement issues given the controversial nature of the evaluation of judicial precedent as a source of criminal law (Criminal Law, 2015 \& Daniel E. Hall, 2015). 


\section{Technology Rules of Actual Mistakes Qualification Modeling}

The criminal defendant may choose to argue that the accused - he or she - was not intending to commit a crime and that the act of crime in many situations occurred as result of a mistake of facts regarding the crime's circumstances or a misunderstanding concerning the law at the time. Such facts mistakes can be applied to a variety of criminal activities, but law mistakes are only rarely allowed as full defenses to criminal conduct (Elliott, 2014). "And things are there", in article 131 of the Criminal code. The legislator does not give more changes, enforcement or leaves on the position in the objective imputation, or in disregard of the requirements notes. No other ways are exsisted. An example of a single norm is possible to speak about the actual mistake, when the wrong idea of the subject about the object attacks can affect the qualification of the offense. Legislator violents sexual crimes classified as non-violent acts of nature on the grounds of committing such in regard to the victim with a special status - helplessness, motivated not by the attainment of the twelve years age (Thibeault et all, 2014).

The defence of mistake may be used along with self-defence and crime-prevention to show that the defendant mistakenly believed he was under attack or was using reasonable force to prevent a crime. The mistake must be honest according to this principal, although they do not necesseraly have to be reasonable. In this case, the question arises respecting the qualification with the actual mistake. It should be noted the need, to the exclusion of objective imputation, establishing intent in respect to all objective elements of the offence subject. For imputation of symptom of failing victims of the age indicated in the note to article 131 of the criminal code, should establish awareness of the subject in this age criterion. Even in cases when the legislator does not specify the sign of "semidomestic", one should proceed from his commitment in finding it. Mistakes in the assault object occur when a person, believing that the violation of some social relations that actually causes harm (or, at least, creates a threat of such damage) to others. In this situation, qualification of actions carried out in accordance with the direction of intent.

Morover, abandonment is not recognized in all jurisdictions. The defendant must completely and voluntarily deny and reject all criminal purpose. Any issues that come up during the act of the crime like the offended resisting or missing equipement needed to accomplish the crime mean or any other circumstances that increase the probability of getting arrested mean that the abandonment was not complete and voluntary. Postponing criminal activity to another time also renders abandonment invalid.

The application notes to article 131 of the Criminal code is an example of the contradictions in the theoretical and legislative positions. It is probably to explain the the legislator approach, though is not contrary official source of law Criminal law, but the official explanation - the decree of the Plenum of the RF armed forces. Consideration of the specifics of law mistakes keeping in mind congnitve analisis based on information development trends of judicial reporting(Daniel E. Hall, 2015) is also essentiel.

\section{Findings and Discussion}

The above problems create difficulties in understanding the actual content in the criminal law norms, and therefore can cause miscarriages of justice in the practice and theoreticalmeaning.And here we come to the question how to be, if the actual emistake is a result of incorrect legal requirement. It is set there is no norm (Gauhman L.D., 2013) that contain provisions that would specifically address issues of criminal responsibility in the presence as factual mistakes in criminal legislation in Russia. There is a controversial controversial regulatory formula, what provisions entail certain difficulties for law enforcement. The complex nature of law enforcement responses technology method's modeling has become an issue of concern.

Factual mistakes often add up very difficult and ambiguous to be solved in theory and in practice. They may cause the situation that needs to regulate legally in such permission.Actual mistake is faulting unlike a person acting under the conditions of misconceptions about the legal properties of the committed acts in such situation. There is no doubt in a true criminal nature of his assault, but an assessment is mistaken as an objective content. The actual mistake is in an incorrect representation of the person's very about the actual content or actual consequences of his acts. Accordingly, it may revision object characteristics as an objective side, committed a criminal assault. The legal factual mistakes and sensibly are written a lot in criminal Russian law. There are ways of permits enforcement conflict that are composed of algorithms for their solution. It is not always possible if we apply the resolution method to specific criminal activity. L. D. Gaukhman in his the academic handbook wrote the qualification rules and offers algorithms for solving mistakes in the criminal law. If a guilty, intending to rape a child, actually committed the assault against the victim, were not such, he needs to answer for the attempted rape of a victim under the age of fourteen (Gauhman L.D., 2013).

In simple language permissive provisions on the problems of qualification if there is an error of the subject, in the 
literature there are and disputed the findings. One of the authors made the following conclusion regarding the misconceptions of the subject in the person of the victim (for example, instead of one person killed the other or mistakenly raped another victim). Of course, this error will result in the application of the rules of qualification completed acts. But $A$. Yu. Prokhorov proposed a different rule qualification, defined as follows, if the offender, intending to rape a child, actually committed the assault against the victim, he needs to answer for the attempted rape rape victim at age under 14 years old. When a person come really close to crarrying out illegal or criminal activity but doesn't actually commit anything, this is called an attempt. The person may have completed all the necessary steps (or thought he did) then stopped because of technical failure or abandoned the crime. Planning and preparation alone do not enough to call and attempt, there must be steps beyond that. It is distinguished from other inchoate offenses like conspiracy to commit, or solicitation of a crime. Attempt of murder is one of the types of attempt offenses and they may vary by jurisdiction. Carrying out the crime will generally lead to more sever punishment that would come drom attempt alone. Depending on how far the offense has progressed, abandonement may be a reason to state a not guilty defence, the abandonement must be free and voluntary. Attempts were not punishes by early common law; common law only recently recognised the law of attempts (Jonathan, 2015).

Mistakes of fact is don't matter unless born out of forgetfulness or unconscious ignorance. intentional mistakes will lead to civil liability.

A mistake of fact may be raised by one party as a defense to escape liability under the contract. Mistakes of facts can also be used to cancel, rescind, or reform a contract. Only fact that is of material value and important to the contracted agreement can affect a contract.

Of course, it is not enogh to talk about the assassination at the time, when we deal with ended act, but also to impute responsibility for the attempt and the completed offense, violating the requirement that liability for a crime is impossible. Should we pay attention into the doctrine the law, whether judicial practice is brought of law enforcement authority? But, first of all, the legislator should contact the law enforcement authority to such legislative text formulas that will not come to a deadlock. Unlike criminal law, mistake of civil law can quite easily provide a defence to a criminal charge, on condition the actus reus of the offence is actually of legal intent. In the case of a unilateral mistake, only one party to the agreement is mistaken about meterial fact and the mistaken party cannot void the contact, unless there's proof that the other party knew, and should have known and had a duty to disclose the first party's mistake.

Among the fundamental principles that protect the rights of the accused to legal assistance of a qualified attorney, is the trial right trial by jury, the right to due process. Due process covers some basic aspects of justice was accused in this article. This includes the right to attend the court and charges information in the state, what is be able to present in court. It is important to explore the issue of criminal legal error when the wrong person evaluates the legal or factual circumstances of the crime.

\section{Concluding Remarks}

Today's generation of young people must come back to understanding and emotional experiencing of the fact that study and work is a serious tension and self-overcoming. Work generates in a person a sense of his own importance, positive changes as a result of effort. Self-development of the man in work is connected with the appearance of opportunities for further choice, with increasing the degree of freedom of action. And, in our opinion, it is the system of higher education that should lay the foundation for such understanding of the process of professionalization in everyone's life, to predetermine the guidance under today's rapidly changing social, economic and technological conditions. the study showed that workers with a higher level of professionalization are more successful in work. They lose less time, they cope with production norms and confidence in their own professionalism lets them disclose abilities in other areas. It is found that this type of workers is more common in the authoritarian and liberal type of management. Workers with a high level of professionalization are mostly women with work experience of more than 3 years in the profession who has never changed their place of work.

For a young worker it is necessary to understand clearly that he can become a professional only with his own efforts. Self-development, self-organization and self-determination are the principles of successful professionalization.

\section{References}

Australian Estates P/L v Cairns City Council (2015) QCA 328 SQL Queensland.

Catherine, Elliott (2014) French Criminal Law. Devon: Willan Publishing.

Criminal Law (2015) H\&M. Retrieved 5 May 2015. 
Daniel, E. Hall. (2015) Criminal Law and Procedure. 6th edition. Wadsworth Cengage Learning, 2015.

Gauhman, L.D. (2013) M.: Qualification of crimes: law, theory, practice. M.: ZAO "Orinfor".pp. 576.

Elements of Crimes. International Criminal Court (2011). URL: http://www.icc-cpi.int/NR/rdonlyres/336923D8-A6AD-40EC-AD7B45BF9 DE73D56/0/ElementsOfCrimesEng.pdf. (15.05.2012).

Harald, Renoul (2015) Droit pénal général. Paris: Paradigme.

Paschenko, E.A. (2012) Problems of qualification of crimes against sexual inviolability of minors. North Caucasian law Gazette. Scientific and practical journal. No. 3. pp. 62-65.

Thibeault, Irina V., Prichina, Olga S. \& Goreliva, Galina V. (2015) Cognitive Russian modeling in the system of corporate governance. Mediterranean Journal of Social Sciences Vol 6, No 2 (2015) http://www.mcser.org/journal/index.php/mjss/article/view/5828.

Thibeault Irina V., Prichina Olga S.,Panfilova Elena A., Karanashev A., Karasheva A. (2014). Russian formula of corporate governance: cognitive modeling. World Applied Sciences Journal 32 (10): 2156-2166,ISSN 1818-4952 ๔ IDOSI Publications, DOI: 10.5829/idosi.wasj.2014.32.10.1339.

Jonathan, Herring (2015) Criminal Law. Palgrave Macmillan Law Masters. 7th ed. Palgrave Macmillan. 